\title{
The Independence of Justice - An Analytical Perspective
}

\author{
Alexandrescu RM* \\ The Parliament of Romania, Chamber of Deputies, Romania
}

*Corresponding author: Dr. Radu Michael Alexandrescu, The Parliament of Romania, Chamber of Deputies, Str. Izvor, no. 2-4, district 5 Bucharest, Romania, Tel: +40744324646;

Email: alexandrescu.michael@gmail.com

\section{Research article}

Volume 3 Issue 3

Received Date: August 08, 2020

Published Date: September 17, 2020

DOI: $10.23880 /$ phij-16000150

\section{Abstract}

Our study clearly shows on the one hand how the judicial power which is in the service of the sovereignty of the community and individual rights can be functional, and on the other hand it offers quite a detailed scale of reference for the current debates on the matter of judicial power in Romania; our results are meaningful for comparisons and further research.

Keyword: Definition of justice; Constitutional setting; Judicial system; Independence of justice; Accountable justice

\section{Setting the Matter}

The introduction of texts usually serves as guidance for the readers made by the author regarding the manner in which the latter believes the text should be read; this introduction respects the tradition, the custom. The surprising fact may be that in the recent Romanian context a study on the independence of justice no longer needs motivating: it is such a frequent topic that any contribution is considered natural. This being the situation, it is downright necessary to mention that the implicit motivation does not work in the case of this text; on the contrary, this text would be most adequately perceived out of context. Hence what it proposes is a conceptual analysis of several fundamental topics, a description (which is volens nolens accompanied by an assessment due to precisely the fact that theoretical background presented here is sine qua non for any constitutional and legal setting in which there is respect for human rights, democracy and the rule of law) of some matters and solutions relating to topics such as definitions of justice, types of justice, the rule of law, the separation of powers etc.. Simply put, the analysis is a rather philosophical one with the finality of forming simple and clear architectonics of the topics mentioned in the above. Through a second step, also present in this text, the analysis aims to highlight the manner in which these major topics with philosophical and in particular axiological contents are applied, embodied in the form of constitutional arrangements that make the transition from the theoretical generality to the concreteness of social action. Only in a third and final step the text reveals several standpoints of Romanian specialists on the topic of the independence of justice in the manner in which they understand it in the Romanian context.

To put it more clearly: I propose taking it out of context in order to avoid parti pris as much as possible, I aim to establish in an analytical, descriptive manner the architectonics to which the topic of the independence of justice pertains; I argue that precisely in order to avoid biases, the assessments and preferences in favour of a certain positioning on the topic needs to simply derive from the description of the architectonics, conjugated with the fact that it is applied through constitutional arrangements in societies that are considered landmarks in terms of human rights, democracy and the rule of law; hence the intermediary step on the manner in which justice and its independence present themselves in two types of fundamental constitutional arrangements. Finally, since from the aforementioned we can understand two things - (a) the fact that we designed an architecture on two levels, a general theoretical setting, of a rather philosophical nature; and (b) the fact that the application of this structure occurs in the Western world in the form of two fundamental types of constitutional arrangements - then it would be expected that in the third step I refer directly to realities, to facts regarding the independence of justice in Romania. I 


\section{Philosophy International Journal}

do not do this due to multiple reasons: 1 ) in order to avoid being blamed for making up facts; b) because these facts are right in front of us, in multiple forms of representation, to be honest; 3 ) because by presenting assessments of several specialists on these facts I offer a reading framework that is not just neutral but also more nuanced about the facts, about what we need to remember. But. once again, the finality of this text is not just that of being one more standpoint in an already ultra-ample discussion.

The finality of the text, the one standing as the motivation behind it, the one which can give meaning to it is in itself polymorphous: to remind (because I refuse to believe that it is not known) what constitutes the large concepts of a discussion on justice and human rights, on law and democracy, ultimately on what cannot be absent as a theoretical support to any analysis of justice; then, the finality of the text is to show that the actual situation of the justice depends on constitutional arrangements, on the manner in which the protection of human rights, of democracy and especially of functioning of justice is stipulated in the constitution; thirdly, the text seeks to show that the reading, the interpretation of the facts, even when made by specialists, cannot step out of this cascading route of the operationalisation of the independence of justice. If at a theoretical level one is not interested in human rights, it becomes impossible to protect them at the level of the polis and all the less at the level of the infra-constitutional laws, and the specialists - provided they respect their profession and acknowledge the importance of human rights - simply become contortionists or they embarrass themselves. From the above it is understood that there is a close logical relation between the three levels; the health condition of each of these constructions (theoretical architecture, constitutional arrangements, interpretations of the facts) has serious implications on the others.

What the text could be criticised for would be that it is not positioned towards concrete facts, towards quotidian events. I clearly stated and I repeat that there is a sufficient number of voices already doing it and as it can be noticed, that is not the finality of this text. Therefore, once more, the method is almost dogmatic, the analysis of the ideas, of the concepts and theories (of course, it is brief but sufficient, I hope). Regarding the structure of the text, it is dictated precisely by its logic presented in the above. In the first part, I propose the description of the theoretical architecture of the invoked topics; in the second part I exemplify through constitutional arrangements referring particularly to the justice from the Anglo-Saxon system, from England, respectively from the continental system, from France. In the third and last part I present a few standpoints of several Romanian authors on the independence of justice in Romania. It is sufficient to mention once more that the readers of this text should have at the end of reading it a minimum of instruments necessary so that they can themselves make an interpretation of the state of the Romanian justice with decent means from a knowledge perspective. One cannot expect more from an educated citizen; which does not mean that a citizen lacking these instruments is less of a citizen and has less of a right to decide for all of us.

\section{Justice}

However seductive the development of some essential but collateral topics may be, I will limit myself to the attempt to formulate brief and clear answers to two questions (especially to the second one). The first question: why do we treasure justice? (this assuming that we do treasure it, that we are not just hypocrites or assuming that by justice we do not understand a bare right of the strongest). The second one: what do we understand by the term justice? (the answer to this question has a direct impact on the reason why we treasure justice). The solutions for the first issue are usually placed in the category of the foundation of justice; the solutions for the second issue are placed in the category of the definitions of justice or types of justice. Given the close relation between the answers to these two questions, regardless of which we begin with, there are inconveniences. The choice of starting with the solution to the matter of the foundation of justice is commanded by the prevalence of the interest for the relation between the two problems. Another mention is necessary, the mention that the term justice is used in different contexts; the two questions regard the moral, respectively the legal context; the answers to each of these questions can lead us towards both the theory on morality and towards the theory on justice; as we will see below, the answers to the matter of the foundation of justice most often lead to ethical considerations on morality - the reason is that the arrangements of a legal nature are also ultimately relating to morality, to the values of the community of citizens by means of the constitution - ; whereas the answers to the matter of the definition of justice frequently refer to the legal field, the one that interests the justice - the reason being that the dominant standpoints on justice in the community are ultimately best expressed in the legislation -. To put it briefly, from these considerations we understand that a discussion on the independence of justice regards not only its organisation, its positioning towards the other powers in the state, but also the manner whereby through the constitutional arrangements it relates to a dominant definition of justice and to the manner in which it is supported by the community, by its moral and values.

In the regard of the foundation of justice, ever since the Antiquity sophists (see Glaucon's arguments in Republic $360 \mathrm{~b}-360 \mathrm{~d}^{1}$ ) claim that there is no subsistent foundation of

1 Plato, Republics, in Plato, Complete Works, Indianapolis/Cambridge, Hackett Publishing Company, 1997, p. 1000-1001. 


\section{Philosophy International Journal}

justice (such as, for example, the form of justice advanced by Plato through Socrates in the dispute with Glaucon), the only foundation of justice being of a social nature, the fear of punishment or of public disgrace; otherwise, humans only have the grounds of selfishness, of the inclination toward gain. In other words, the valuing of justice is the result of a hypocrisy born out of fear. The one who has the possibility of overrunning fear through natural strength or through deceit such as Gyges is not interested in justice, but in one's own gain. After over 2000 years, in a more elaborate but not less direct form, Nietzsche supports the right of force as the natural law; justice understood as dominium of the strong will despises its traditional grounds; it is significant, for instance, that there is explicit criticism not only towards Kantianism or Christianity, but also towards the famous principle of Schopenhauer in matters of moral, neminem laede; imo omnes, quantum potes, juva, in the name of the will to power (for example, Jenseits von Gut und Böse, $186^{2}$ ); the right of the strongest is not even halted by the alleged subsisting grounds of justice, all the less could it be halted by the social contract.

The opposite standpoint is that there is a ground of justice, ground of a nature either subsisting outside humans and absolute, or rooted inside humans and therefore prone to error even though through itself it tells us to cherish justice and even what justice consists of. Regarding the conception according to which there is a subsisting ground in itself of justice outside of humans, the platonic standpoint is the first classic example in philosophy; the foundation of justice is the form (eidos) of justice, a form of an absolute nature, through the participation in which there is justice in the material world of the copies (for instance, Republic 479a $\mathrm{a}^{3}$ ). In theology, another classic standpoint is the one of Augustine, for whom (otherwise, as for any Christian theologian, regardless of the confession) the foundation of justice is God (for example, De Trinitate, III,IV, $\left.9^{4}\right)$. Modern thinking holds in essence the preference for a subsisting foundation of justice but, in accordance with its rationalism and the interest manifested towards the individual, it locates this foundation inside every human being (thereby attracting various limitations in its functioning, limitations that at the same time play an important role in explaining why it is that there is injustice when humans bear in themselves the grounds of justice). Therefore, for Rousseau the foundation of justice is in the sentiment, meaning in the conscience understood as an enlightened - by the reason - sentiment, and it consists of two principles, the search for one's own wellbeing and the

\footnotetext{
2 Friedrich Nietzsche, Jenseits von Gut und Böse, Berlin, de Gruyter, 1999, pp: 106-107.

3 Plato, op. cit., p. 1106.

4 Aurelius Augustinus, De Trinitate, III,IV, 9 în https://www.thelatinlibrary. com/augustine/trin3.shtml, accessed on August ${ }^{\text {th }}, 2019$.
}

avoidance of the suffering of others (for example, Emile ou De l'education, livre $\mathrm{I}^{5}$ ). For Kant - who makes the same modern distinction between sentiment and reason, but he defines and valorises them differently than Rousseau - the foundation of justice resides in reason, in duty, in the absence of any inclination of the sentiment (for example, Immanuel Kant, Grundlegung zur Metaphysik der Sitten, I. Abschnitt ${ }^{6}$ ).

As we showed, the basis of justice refers both to the foundation of moral justice and to that of legal justice. Ever since the ancient sophists, there has been the idea of the opposition among nature and society, and the one of the social contract. In modern times, the social contract most frequently thought of as a piece of legislative fiction - acquires prominence, considering that it is expressed in constitutions so that it offers the basis for legal justice. Regardless of whether the existence of a ground of justice is assumed distinctly from the social contract - as in most of the mentioned cases -, or whether the social contract itself becomes a ground of justice ${ }^{7}$, it is important to note that when discussing about the social contract and the constitution we enter the sphere of the ground of legal justice, justice whose definitions we will briefly analyse in the following. The connection between the topic of the foundation of justice and that of the definition of justice is accomplished at a practical level through constitutions; in none of them - regardless if they are ancient or modern and independently from the definition of justice - the infringement of justice is not stipulated; on the contrary, the necessity of supporting the justice is strongly advocated. There is no stronger evidence of the importance of the topics of the ground and definition of justice and of the relation, including the theoretical relation, between them, other than this concrete situation of the constitutional provisions in matters of justice of any state.

Covering the topic of the definition of justice, even though it also includes moral aspects, we are fully in the sphere of legal matters. The definition given to justice forms the basis for constitutional provisions and these represent the reference framework for infra-constitutional laws. All modern constitutions - as, otherwise, most of the ancient ones - propose the equality before the law, the rule of law or the so-called procedural justice, isonomia, as the ancient called it, as a definition of justice. For this reason, at the level of common sense, the necessity of discussing this topic almost disappeared; we all think we know what it is about without

5 Rousseau JJ, Emile ou De l'education, Amsterdam, Jean Neaulme Libraire, MDCCLXII, Tome premier, pp: 112.

6 Immanuel Kant, Grundlegung zur Metaphysik der Sitten, Leipzig, Dürr'schen Buchhandlung, 1906, pp: 14-17.

7 In modern philosophy, usually, the social state has to conform itself to natural law (so Locke, Rousseau etc.), but there are cases when the social state has to tame the natural law (so Hobbes); generally, social state is defined under strong conditioning of the natural state. 


\section{Philosophy International Journal}

analysing things. This is in fact a reason for insisting on them and for starting to discuss the definition of justice with this stance, justice as the rule of law, procedural justice. The classic example that I will immediately discuss is the concept, the definition, proposed by Hayek; however, precisely because I refer to the rule of law as procedural justice, I prefer to start with a fundamental distinction, the one between procedural or formal justice and distributive or material justice. As their names show - and as it will be shown below - in the first case the definition of justice is made based on procedural, formal criteria, and in the second case, based on contentrelated criteria (hence the material in opposition to the formal: the term content referring to the characteristics of the subjects of justice, in opposition to that of formal which shows that precisely such characteristics are indifferent). Another mention is important for the correct understanding of the proposed definitions; when we analyse a definition of justice, we need to consider not just the theoretical context in which it appears (on which assumptions it is based, what concepts there are and how they relate to each other, what the theoretical implications of the definitions are), but also the manner in which it functions at a concrete level (the main issue is whether through operationalisation, application, that definition has consequences that strongly contradict the theoretical findings).

As we already mentioned, Hayek is one of the most important contemporary proponents of procedural justice, of the rule of law which he understands as durable, stable, public laws and, especially, the same for all (for example, The Constitution of Liberty, II, 10, $4^{8}$ ). This definition of justice was born in England, and we owe the expression rule of law to Albert V. Dicey; as Bingham states "all persons and authorities...should be bound by and entitled to the benefited of laws publicly made...and publicly administered in the courts"'. This definition of justice is stipulated as such or in another form in all the modern constitutions. It is acknowledged, as its great advocates state, as the fundamental condition for freedom, the most important guarantee for the respect of the negative rights of the individual, not just of the citizen (life, property, freedom). There are almost no open stances contesting it (as we will see immediately; previously, the situation was different); however, less convenient implications of procedural justice are highlighted; firstly, the inequality of rewards which questions the equality of opportunities or even equality of treatment (of course not at a theoretical level, but at a practical level; theoretically, nothing states a billionaire could be treated differently than a homeless person; in practice, the situation is different). Before analysing the definition of justice proposed by Rawls,

8 Friedrich Hayek, The Constitution of Liberty, Chicago, The University of Chicago Press, 1978, pp: 153.

9 Tom Bingham, The Rule of Law, London, Penguin Books, 2011, pp: 19. through which he tries to offer solutions to such issues, it is worth mentioning some classic definitions of distributive justice.

A classic example of distributive justice is the so-called justice according to merit (the terminology is deceiving because it suggests a false overlap with the procedural justice which implies, for equal treatment, different outcomes depending on the merits of the individuals), the Aristotelian one. Justice is defined based on act and potency as the ability to actualise an asset; hence a flute has to be given to the one who knows how to sing; in case of competition, it has to be given to the one who has to a larger extent the ability for its actualisation; in the situation in which there are multiple individuals with the same relevant merit and multiple assets of the same kind to be distributed, in accordance with the idea that virtue is a mean/mesotes, the goods are not distributed, are not given, only to the one who has to the largest extent the relevant merit, but they are distributed among all who have that merit (who can actualise the goods) proportionally with the extent to which those individuals have the relevant merit. Aristotle warns that a constitution is fair when there are as many relevant merits as possible stipulated therein, in order for the distribution of the goods (who to hold public offices, who to produce etc.), but especially the structuring of citizens in the polis to be diversified to a maximum, satisfying all social functions (for example, Aristotle, Politics, 1282 a, $36-1284$ a, $17^{10} ; 1287$ a, $11-1287$ b, $7^{11}$ ).

The sophists - I herein use the manner in which Glaucon expresses their positioning, because Plato is particularly recognised as a credible source - in accordance with their position on the foundation of justice, although they are the first to distinguish between the natural state and the social state, define it as natural law, the right of force, of the strongest. Of course, as shown above ${ }^{12}$, they are ready to admit the coercive force of the social contract, but at the same time they state that based on their natural division between the strong and the weak, the strong will obtain more, and the weak will appeal to the social contract in order to try, as well, to obtain as much as possible, as Callicles states in the Gorgias dialogue; hence to sophists, the avoidance or the infringement of the social contract, far from posing a problem, is even desirable when it occurs as an affirmation of natural force (for example, Plato, Gorgias, $483, \mathrm{~b}-\mathrm{d}^{13}$ ).

Another distributive type of definition of justice is the one proposed by Marx as a reaction to the ideas on justice

10 Aristotle, Politics, Indianapolis, Hackett Publishing Company, 1998, p. 84-89.

11 Ibidem, p.96-97.

12 Vide supra n.2.

13 Plato, Gorgias in Plato, Complete Works, op. cit., p.827-828. 


\section{Philosophy International Journal}

advanced in the platform of the Social Democratic Party of Germany at its Congress held in Gotha in 1875. Briefly, in his criticism, Marx is closer to the solution which Bismarck proposes a few years later for ensuring social security, namely based on the contributions of the employee - at least in the first phase of communism, the socialism-, rather than the solution being close to the propositions of equalitarian distribution, regardless of the contribution of each individual to the production of the goods, supported in the platform of the SDPG. What interests us is what Marx outlines as a definition of justice for total communism: from each according to the possibilities and ability, to each according to his needs, in the conditions: (a) of a technological development allowing the production of an abundance of goods and services, and (b) of the transformation of labour into a necessity (for example, Karl Marx, Kritik des Gothaer Programms, I, $3^{14}$ ). It is easy to notice that the choice of a content-based criterion (merit, nature, needs, etc.) for the definition of justice and the distribution of goods allows that this type of distributive definition of justice held both definitions which valorise the natural differences among people to a maximum (the sophists, Nietzsche) and completely opposed definitions, according to which any natural differences are considered irrelevant (Marx) $)^{15}$.

Each of these distributive type of definitions of justice implies serious inconveniences. Hence, justice according to merit - as Hume had already shown - except for the situation in which the merit is established by an infallible being, generate arbitrariness; the right of the most powerful - at least if it is affirmed as a principle - destroys any chance of a functional community aggregation; justice according to needs is utopian since it is based on the assumption of the possibility of satisfying any need based on the abundance of goods and services produced, in the context in which it is known that any satisfied need generates other needs.

Given this, several definitions were proposed, having been assumed that they could keep both the advantages of equal treatment before the law and the ones of the distribution of goods, with a significant decrease of the previously mentioned disadvantages. The most well-known of these attempts is the one of Rawls, who defines justice based on two principles (sometimes he discusses about the

14 Karl Marx, Kritik des Gothaer Programms in http://www.mlwerke.de/ me/me19/me19_013.htm\#Kap_II accessed on August 27th, 2019.

15 It can be interesting to briefly mention that from the Beveridge type of solution of a minimal safety net adopted by the Anglo-Saxon welfare state and until the recent proposals (see the Finnish experiment in Sanjana Varghese, Finland's grand universal basic income experiment raises more questions than it answers in https://www.wired.co.uk/article/universalbasic-income-policy-universal-credit accessed on August $27^{\text {th }}, 2019$ ) proposals for an universal basic income, we can recognize a Marxist detail in the middle of all the liberal capitalism theory. As challenging as it is, this discussion which cannot enter the design of this study is also complex. second part of the second principle as a separate principle, the principle of difference). The first states that all the participants to an institution (in our case and, as well, as intended by Rawls, the state) have to enjoy a maximum level of freedom equal to the one of the other participants. The second principle states in its first part that the occupation of the positions which bring advantages desired by everyone in that institution has to be open in an equal manner to all the participants in that institution; in its second part, the principle states that the inequalities resulted through the occupation of the positions need to also be in the advantage of those who obtained less after that occupation. Rawls states that in order for this definition to be accepted in that community of the participants in the institution (here, the state), two assumptions - whereby the original position is characterised - are necessary: (a) the participants are rational subjects interested in their own utility, not in that of others, (b) they are covered by a veil of ignorance regarding both their initial state and abilities and what each of them can hope to obtain from the application of the definition of justice (for example, John Rawls, A Theory of Justice, I, II, $11^{16}$ ). As Rawls states, from the very lexicographical order results the importance of the equality of treatment, meaning of freedom, including in the occupation of positions (equality of opportunity). The equal treatment has to be satisfied in order for the difference principle, meaning the redistribution, to be applicable. Beyond all criticisms - some of them well founded - the fact remains that Rawls attempts to give a unitary definition of justice, a definition that finds its practical echo in all the contemporary constitutions which stipulate both the rule of law and the redistribution, making a connection between them; the two principles can be assumed and applied at a constitutional level by any community.

From the point of view of the discussion that interests us, that about the independence of justice, this review shows us that the justice that is concerned with defending the rights of the citizens through defending the laws meaning, in essence, with defending the formulas specific to every constitution whereby both the principle of the rule of law and that of redistribution are affirmed - is nothing else than a specific part of the community responsible for ensuring the respect of the definition of justice on which that community agreed. From this point of view, justice is not and cannot be independent from the community; it is not a corporation, a foreign body in relation to the community; if it were, there would not be a connection any more between it and the definition of justice adopted by the community. In this hypothesis, the justice should be excluded from the community. From the point of view of the definition of fairness, justice is fully entitled to be independent in the

16 John Rawls, A Theory of Justice, Cambridge [Ma], The Belknap Press of Harvard University Press, 1999, p.52-56. 


\section{Philosophy International Journal}

defence of that definition of fairness which has been adopted by that community and laid down in the constitution and laws. From this point of view, justice is independent from any attempt of redefining fairness outside the existing rules accepted by the community for the change of the social contract. Anybody from the field of justice or outside it who acts against the constitutional arrangements, against the accepted definition of fairness in the community is not only a destroyer of the constitution, but also of that community.

Hence a given community, through its constitution, agrees on the application of a definition of justice, even though only implicitly and even though the procedural aspect, the rule of law, is not explicitly related to the redistributive aspect; from Plato until today, the peaceful functioning of any given community is based on the legitimacy of power, which is impossible without the functioning of fairness as it is understood by the community and stipulated in the constitutions. Of course, despotic power also exists, but it does not operate with the consent of the citizens. The state in general is defined as a monopoly of violence on a given territory, but no viable state can exist through a permanent exertion of violence over all people. In order for the power to not become despotic and to not transform from the holder of a monopoly on violence into a permanent violator of citizens' rights, it is necessary for it to be censured as long as it is not exercised directly by all citizens (which was only possible in the ancient city states of small dimensions ${ }^{17}$ ). The best solution for this censure - regardless of the form of government - is the separation of powers discussed by Montesquieu (without using the term as such) which shows that the union of the three powers, legislative, executive, and judicial will always lead to lack of freedom, to despotism, to arbitrariness (Baron de Montesquieu, De l'esprit des lois, $\left.\mathrm{XI}, 6^{18}\right)^{19}$. These considerations show that justice is not only independent from the citizens, but that it is also a power acting in their name and interest, a public service of maximum importance. Moreover, all the theory on the separation of powers shows that in order for them to be able to control and limit one another, it is necessary that their

17 A reputable specialist in the history of ancient Greece and, especially, of its political regimes, states at the beginning of a recent book the following about democracy: "what the average citizen of a modern democracy takes democracy essentially or substantively to be would have been dubbed, more or less dismissively or contemptuously, by a convinced ideological democrat of ancient Athens"; Paul Cartledge, Democracy. A Life, Oxford, Oxford University Press, 2016, pp. 1.

18 Baron de Montesquieu, De l'esprit des lois in Montesquieu, Tutte le opere[1721-1754], Milano, Bompiani, 2014, p.1218, 1220, 1222 (the best critical bilingual edition gathers multiple previous editions and the manuscript The Spirit of Laws, otherwise recently published online in the Gallica collection at https://gallica.bnf.fr/ark:/12148/btv1b6000035w/ f1.image accessed on September 1st, 2019).

19 The fact that Montesquieu makes these considerations when discussing on the Constitution of England is relevant sphere of operation be perfectly delimited so that neither dominates another, so that they only impose one another the respect of the limitations of operation as they are established by the constitution and laws. When the justice, in the name of independence, pretends to legislate and subordinate the other two powers, it not only becomes despotic, but it also falsifies one of the important principles of its operation, the principle of independence, according to which it must not be dominated by the executive or the legislative. Briefly, this discussion on the definition of justice, on power and on the separation of powers in the state shows us that the independence of any of the powers, not just that of justice, goes hand in hand with the respect for its role in society and with responsibility (political, civic, criminal) before the citizens, and certainly not with the transformation of justice into an idol.

We will better understand these aspects when we apply them to two types of constitutional arrangements regarding justice, the continental one and the Anglo-Saxon one, in the following paragraph.

\section{Two law systems}

Previously, when we discussed the definitions of justice and their echo in constitutions, we showed that almost regardless of the form of government, both the equality before the law and the redistribution can be found; we also noticed the diversity of constitutional arrangements; this diversity is even more obvious when it comes to law systems, to the arrangements in the sphere of justice with the function of the equal application of the law and the redistribution. The diversity of these arrangements related to justice, law systems, allows us to notice which of them is more efficient. The law system in a given state has multiple branches: civil, administrative, criminal etc. Among all, the most important is by far the criminal branch, since it implies the severe restraining of certain fundamental rights of the citizens, first of all of freedom. Regardless of whether the number of criminal cases is the most reduced one, the criminal law keeps its primordial importance from the mentioned reason. Hence, in the comparison that we make among law systems, we refer to the sphere of criminal law. Otherwise, the most important provisions at a constitutional level are related to it.

Given that we referred to the constitution multiple times, it is appropriate to mention that by it we understand a law of a superior level to which the entire legislation must conform, a set of rules regulating the relation of the power with the citizens as well as of the powers among them ${ }^{20}$. For this

20 Neil Parpworth, Constitutional and Administrative Law, Oxford, Oxford University Press, 2012, pp. 3-5. 


\section{Philosophy International Journal}

purpose, the constitution has to accomplish four conditions: to establish the form of government, meaning to provide a foundation for the government system, not to derive from it; to stream from a power exterior to that system, in the case of democracy, from the citizens; to be a law superior to the others; to have an important tradition ${ }^{21}$. In accordance with these conditions, an overwhelming majority of specialists agree that there are not only written constitutions like in the case of France, but also unwritten constitutions as in the case of Great Britain ${ }^{22}$.

Therefore, we covered some steps of our argumentation, starting with the definitions of justice, followed by the manner in which they are operationalised, and concluding with the manner in which constitutions comprise provisions drafted in order to accomplish the accepted definition of fairness, which in the case of modern societies implies the respect for human rights, democracy, and the rule of law. We also showed that these ideas on justice and their corresponding constitutional provisions are very important for the defence of the rights of the citizens, especially for the defence of life, freedom and property, a reason why the criminal aspect of the legislation is the most relevant in the context of our discussion. Hence, we can find even in constitutions certain provisions relating to criminal law. These provisions refer to the architecture and basic operation of criminal justice. This branch of criminal justice holds a fundamental role. Starting from the definition and provisions on justice and the rights accepted in the community, and considering the fact that people are not angels, it is inevitable that some infringements of the law occur. The role of justice in its entirety, but especially of criminal justice is to correct the infringement of rights, the disorder generated by this infringement.

Hence, the main purpose of justice is that of reinstating social peace, a fundamental condition for the solidarity of the community, in the absence of which we cannot even think of prosperity, meaning that even individual wellbeing is excluded $^{23}$. It is fundamental to understand that the role of criminal justice is so important precisely because depending on the severity of the infringement of laws, the community cannot leave the resolution of conflicts to be the responsibility of private entities, of civil law, but it imposes the resolution

21 Ridley FF, There is no British Constitution, Parliamentary Affairs, 1988, 41:3, pp.340-361, pp. 342-343 in https://drive.google.com/file/d/0B1DxBC5idJQYzZINTNiOGYtMGNiOSOF accessed on September 2nd, 2019.

22 John Alder, General Principles of Constitutional and Administrative Law, New York, Palgrave MacMillan, 2002, pp. 39-60; Hilaire Barnett, Constitutional and Administrative Law, New York, Routledge, 2013, pp. 2339; A. W. Bradley, E.D. Ewing, Constitutional And Administrative Law, Harlow, Pearson, 2007, pp. 4-8; each of these studies includes many other references.

23 And if they cannot correct or cannot hope to correct the various injustices, in the context of freedom of circulation, those individuals leave the community. of these conflicts in accordance with the definition of justice that is accepted by its representative, the state, in particular by the judicial power, meaning exactly the criminal justice.

These are the reasons why our attention is directed towards the criminal branch of the law system. There are many aspects that would require a concrete discussion for the case of every state and law system: what the specific constitutional provisions - on the separation of powers, on the judicial power - are; what the organisation of the criminal branch of justice is in every state; what its concrete operation is; what are the actual relations among the representatives of the various powers; whether there are real verifications and balancing among the powers; if the justice is responsible before the community that it should serve etc. We answered some of thesequestions, whetheritbeonlypartially, discussing about the separation of powers, on the judicial power, and when it comes to other questions - in particular regarding the relation among the powers, the concrete operation of justice, and its responsibility, I will make a few references in the following paragraph. For now, I want to note that in order for a justice system to be functional or successful, the organisation of the fundamental event of criminal law, that is, the criminal trial, is essential. It implies a discussion on the type of infringement of the law, on the type of court that is ruling, and especially on the rules according to which that court rules and delivers a given sentence. A sentence which in principle, meaning at a fundamental level, has to comply with the standards of the community in matters of justice (which in the systems of positive law are assumed to be expressed through laws, firstly, and in the systems of common law, in precedents and especially in the morals of the community expressed through the opinion of the jury). More simply stated, whichever the answers to the other topics that we just mentioned may be, we can see the connection between these answers and the fundamental topic of the organisation of the trial. It is a fundamental topic because it is the point where the community (twice, as the plaintiff and also as the judge and/or jury), the definition of justice and the laws, the traditions, the individuals meet; it is there that decisions are made that can generate or not generate social peace, solidarity, and the wellbeing of the community and of the individuals. By stating this, we answered at least implicitly to a question that could be formulated, that is, regarding a functional, efficient or successful justice system. Regardless of the number of theoretical disputes on the advantages (and disadvantages) of one type of organisation of criminal justice or another, regardless of the number of arguments and their force, what eventually matters is the feeling of fairness shared by the community and the individuals; the trust in the justice system. They are hard to measure and even harder to build over tens, even hundreds of years. This feeling of justice, generating trust, firstly stems from the affirmation of the community as a final judge to its members. It is not the 


\section{Philosophy International Journal}

theoretical competencies of prosecutors, lawyers or judges that are fundamental for justice and the level of trust in justice, but the participation of the community - according to clear and transparent regulations - in every criminal trial; that participation educates that very community and legitimates the verdicts. A given people is free and a community is solidary when they learn in hundreds of years to defend their justice. Taking all this into consideration, we can continue with a brief description of two types of trial, the one from the law system based on tradition, the Anglo-Saxon one, as well as the system based on explicit legal provisions, on positive right, the continental one.

Hence, we refer to the organisation of the criminal trial, meaning to those procedural aspects that are fundamental for the feeling of justice and for the trust in justice. For space-related reasons, we refer to the organisation of trials in Great Britain (in England and Wales in particular), as well as in France (given the level of the influence of judicial literature, the German system should have been chosen; however, since the French system was taken as a model in Romania, it is appropriate to discuss it). Great Britain has a law system of common law in which the infringements of the law are divided based on gravity into three classes: the summary judgement ones, the indictment ones, and also the ones that can be tried either in the first or in the second. Summary judgement trials are held in Magistrates' Courts, the others in Crown Courts; the large majority of cases are of the summary judgement type. For these legal actions, the trial is conducted by magistrates, among which a district judge presiding these courts, but oftentimes there are three unspecialised magistrates (advised by a judicial advising officer) that pronounce the sentence ${ }^{24}$. The cases from the other categories and firstly those judged by indictment are the ones that interest us; they are subject to the trial with jurors so that the acquittal or conviction is pronounced by the equals of the defendant, meaning by the community whose regulations were infringed. That trial is known as an adversarial type of trial. The adversarial system functions not only in Great Britain, but also in the former British colonies. Beside the essential characteristic of the jury trial, other several fundamental characteristics are meant to defend the rights of those subjected to trial: the defendant is assumed to be innocent until the final ruling; the individual subjected to trial cannot be obligated to self-incriminate; acknowledgement of guilt cannot represent self-standing evidence; all phases of the trial are public; the trial has a pronounced oral character. But alongside them, even more important is the adversarial organisation of the trial, the fact that the parties involved in the trial have the same force;

24 Andrew J. Ashworth, United Kingdom in Kevin Jon Heller, Markus D. Dubber (eds.) The Handbook Of Comparative Criminal Law, Stanford, Stanford Law Books, 2011, p. 534. hence the prosecution proposes their own evidence and witnesses whom they examine and whom are examined by the defence as well, after which they are re-examined by the prosecution (the so-called the case for the prosecution), and the defence, in turn, proposes their own evidence and witnesses whom they examine and are afterwards examined by the prosecution as well, and then re-examined by the defence (the so-called the case for the defence); each party puts forward a final plea in the closing of their own case. The judge is a umpire overseeing the respect of the rights related to the undergoing of the trial, and at the end summarises the case, instructing the jurors on the relevant legal provisions; if the defendant is found guilty, the judge is responsible for the task of formulating the sentence, meaning the legal classification of the offence in the tradition of common law sanctions, meaning in precedents, when there are no positive law provisions available ${ }^{25}$.

The advantages of this adversarial system are obvious: the opinion of the judge (or the theory that the judge formed in relation to the offences) cannot influence the resolution; this theory cannot obstruct the presentation of evidence or witnesses because it wouldn't suit the pre-set opinion of the judge; this adversarial system corresponds both to the optimum manner of looking for the truth, which is through the presentation of opposing arguments, and to the condition of a free man, of the citizen equal to the state (moreover, before the 80s, the Crown Prosecution Office did not even exist, all the investigations having been made by the police without any other guidance, while the prosecution was supported by lawyers employed by the state - advantages that start to get lost in the British system as well, although barristers for the state are still employed from the free market). The main negative aspect of such a system is that the presentation of the case for the prosecution, and also for the defence, is largely dependent on the quality of attorneys, which depends on the financial resources of each of the parties involved ${ }^{26}$.

The organisation manner of criminal trials in France has origins in the Code d'instruction criminelle of 1808, an imperial document reflecting rather the will of the power than the rights of the citizens; a document whose provisions have not significantly changed over the past 200 years - the only slightly important amendments, the ones introduced between 1992 and 1994, did not change the essence of the Napoleonic Code - in a state whose regime is not rarely regarded as similar to an elective monarchy ${ }^{27}$. The offences subjected to criminal

25 Janet Loveless, Criminal Law, Oxford, Oxford University Press, 2012, pp. 20-21.

26 Daniel E. Hall, Criminal Law and Procedure, New York, Delmar, 2009, pp. 285.

27 Catherine Elliott, French Criminal Law, New York, Routledge, 2011, pp. 35. 


\section{Philosophy International Journal}

justice are divided into three categories: minor, major and serious; only for the latter ones, which are subjected to trial by the courts of the highest level, Cours d'assises, the decision is formulated by a jury; the jury is however composed of three magistrates and nine citizens; all the other cases are ruled on by lower-level courts of magistrates. The system of organisation of trials on the continent, among which France is exemplary, is an inquisitorial system. It is a system in which the representatives of the state have the obligation of discovering the truth by searching for and presenting evidence and testimonials, through the written drafting of a file containing them. The criminal investigation has three phases: the investigation made by the police and prosecutor, the investigation made by the instruction judge (these first two phases are not separated in practice) and the actual trial. The first two phases are not public; the defendants do not have access to the file and neither can they build their own cases $^{28}$. During the actual trial - which is not always public - the judge is very active: he decides what evidence and witnesses are admissible (definitely, this is the most unjust aspect of such a trial), he questions, he directs the search for truth and, inevitably from the debates of the jury, influences the juror citizens (let us notice that in states such as Romania there are no juror citizens). The file comprised in writing in a non-public phase and the inquisitorial and discretionary nature of the actions of the judge during the trial is not tempered by the fact that through the reform introduced in 1994 an increase of the importance of oral, public debate during the trial was attempted; this reform did not change the inquisitorial character of the trial ${ }^{29}$. The fact that the rate of convictions is higher in this system of organisation of the trial in comparison with the common law organisation is rather a clue of the weak guarantees for human rights offered by the continental system, than a signal of its superiority. There is no room here for theoretical debates. Two aspects are sufficient for assessing the desirability of one or another of the systems. The first is of a historical nature; we showed the high regard that Montesquieu has for the political and judicial organisation in England; all the historical testimonials are oriented in this direction. The second one is the following rhetorical question: if you were indicted, would you wish to be publically investigated, in order for you to be able to bring forth the evidence and witnesses you consider appropriate, while your equals in society ruled on your guilt/innocence? Or would it be preferable from your perspective that the police and prosecution gathered evidence without showing them to you, while a judge ruled as he pleases what evidence and witnesses to admit, the judge being, as well, the one ruling on your guilt or innocence? It is certainly a rhetorical question, since any man in full exercise of his faculties, when it

28 Catherine Elliott, France, in Kevin Jon Heller, Markus D. Dubber (eds.) op. cit., pp.214.

29 Catherine Elliott, French Criminal Law , op. cit., pp.13. comes to oneself, would choose the adversarial organisation of the criminal trial.

\section{The Independence of Justice}

We are at the point when we can directly cover the topic of the study, the independence of justice. It is obvious that the topic is important, not just from the recent debates in Romania, but especially from the fact that it is an important topic all throughout Europe, so much so that it lead in 2018 to the publication of a special issue of the prestigious German Law Journal, a monographic issue dedicated to the independence of justice (self-government), in which the situation in numerous member states of the European Union, among which Romania, was analysed in detail. The leitmotif of the studies is that independence without responsibility which is the case in most of the states - is rather negative; as we will immediately see, only the Romanian contributors regard it as a smaller evil than a justice system risking to be influenced because it is part of a mechanism of checks and balances with the other powers of the state. The contribution on the independence of justice in Italy is exemplary; the authors believe that the Italian system of self-government through the High Council of the Judiciary, established in 1958 - which has been exported in other states of the European Union, meaning it is the model based on which the Union currently operates -, isn't accompanied by responsibility: "while securing the independence of the judiciary, the Italian model of JSG has been far less effective in making the judiciary accountable, which in turn may have affected professionalism and diminished public confidence" ${ }^{\prime 30}$.

Going through this monographic issue, even though a philosophical analysis such as the one that we previously realised is lacking, a comforting feeling generated by the efforts of specialists to associate responsibility to independence is inevitable. What we stated in the previous paragraphs lay down the issue of the independence of justice in its natural framework: the accepted definition for justice in the community, the constitutional arrangements guaranteeing the sovereignty of the citizens and their rights, first of all through the fact that the powers are separate and they need to balance each other, but especially in light of the fact that justice should be in the service of the citizen, which is far better noticeable in the adversarial system.

We therefore see that the independence of justice although it is an issue being disputed on, with specialists agreeing only upon the fact that the judge has to be independent in his ruling (which is usually expressed through

30 Simone Benvenuti, Davide Paris, Judicial Self-Government in Italy: Merits, Limits and the Reality of an Export Model in German Law Journal, vol. 19, no. 7, 2018, pp.1641-1669, pp.1667. 
the judge's obligation to comply with the law, in absence of any further observations) - is in fact a matter which implies numerous other determinations; the responsibility, which has to balance the independence, is a sine qua non exigence. In lack thereof, the judge is far more exposed to two fundamental perils: the arbitrary voluntarism allowed by a corporatist structure of the judicial power, and occult influences (of a political or other nature) exerted onto it. Knowing this, it is easy to notice that the manner of organisation of the trial, even when other guarantees are insufficient, is fundamental for the respect of justice. In an adversarial type of trial, the judge cannot accept any evidence of the prosecution, or reject the evidence of the defence.

Taking all this into consideration, and also considering the well-known recent debates on the independence of justice in Romania, in order to have a complete image on the topic which is also applied to the context of our state, the best course of action is to discuss the theoretical stances of specialists in the field.

The independence of justice is a concept that is placed at the centre of serious debates among specialists; debates that also draw attention to the fact that an absolutisation of justice, a supremacy over the other powers in the state holds risks regarding democracy and even the rule of law and the respect for human rights. As we are only talking about an outline of these discussions, we only invoke some of the Romanian specialist who were recently involved in the discussion. The presentation we make is like a crescendo illustrating these risks, but at the same time the fact that these attitudes are in crescendo is dependent on the adopted methods and sometimes even on the preferences of the authors. At the first level, Ramona Coman and Cristina Dallara adopt a purely descriptive method, presenting the various aspects of the Romanian judicial system, from the formation and remuneration of magistrates to the role of the Superior Council of Magistracy; they present these aspects as the ground upon which the independence of justice in Romania relies: "Our intention is less to evaluate the functioning of the judicial institutions than to offer a comprehensive picture of the main changes and the current difficulties that exist relating to the independence of the judiciary" ${ }^{\prime 1}$.

On a superior level - but, at its core, still a descriptive study - lies the contribution of Bianca Selejan Guțan because it acknowledges the risks implied by the institutional setting of the Romanian independence of justice. Moreover, she also expresses a preference for the current status quo in the Romanian judicial system in which the independence

31 Ramona Coman, Cristina Dallara, Judicial Independence in Romania in Judicial Independence in Transition, Anja Seibert-Fohr (ed.), Heidelberg, Springer, 2012, pp: 841. is major, while the responsibility is minor, believing without bringing forth any arguments - that this situation is less risky than the one in which a certain level of control and responsibility of the judicial power were imposed: "Is excessive judicial self-government perilous to the ruleof-law? In my opinion, although the criticisms against the 'corporatization' of the system are partly justified, this 'excessive autonomy', established as a reaction to the high level of corruption that plagues the Romanian society, can be considered 'the lesser evil' in the equation" ${ }^{\prime 2}$.

If until now the crescendo only consisted of the acknowledgment of the perils implied by the out-of-control independence and lack of responsibility of the judicial power, the following two studies that I mention are on the one hand more critical towards an uncontrolled independence lacking responsibility of the justice, and on the other hand the expressed stances are not based on mere preferences any more, but on solid arguments. After showing that in the discussions on the independence of justice the aspect leading to an agreement among specialists is that of the independence of the decision of the judges, Cristina Pârău outlines that the perspective from which the issue of the independence of justice is covered is a normative perspective, meaning an institutionalist perspective; it is an analysis made from the perspective of the constitutional arrangements laid down in constitutions regarding the separation and balancing among the powers in the state. From this perspective, the author discerns among three types of positioning of the justice system in relation to the other powers in the state: subordinate (with a negative form in communism and a positive one in the British constitutionalism), equal (specific to the constitutional arrangements of mutual assessment and balancing of the powers in American constitutionalism), supreme (when it subordinates the other powers, transforming the independence into the lack of any control and of any responsibility, a corporatist type of institutionalisation present in Romania). The author argues in favour of the classic American solution, criticising the Romanian supremacist solution based on corporatism whose main carriers are in her opinion the Superior Council of Magistracy and the Constitutional Court (we however need to state that according to the Constitution of Romania, the Constitutional Court is outside the judicial authority, and the author's reasoning regarding the integration of the Court in this authority is flawed, unlike the solid reasoning at the centre of which there is the Superior Council of Magistracy); moreover, she shows that this type of justice was imposed in Romania by the European Union: "as with any selfperpetuating institution the only checks and balances left

32 Bianca Selejan-Guțan, Romania: Perils of a "Perfect Euro-Model" of Judicial Council in German Law Journal, vol. 19, no. 7, 2018, pp.1707-1740, pp: 1710 . 


\section{Philosophy International Journal}

on the judiciary consist of "informal pressures" exerted by their own peers, or by the media...the autonomizing and augmentation of the SCM's power were not accompanied by adequate accountability" ${ }^{33}$. The analysis by Cristina Pârâu on the action for cancellation - which we briefly present is particularly relevant. Considering the typology of the relation between justice and the other powers in the state as a subordination, equality, or supremacy one, arguing that under the powerful impact of the European Union in Romania the supremacy of justice through the Superior Council of Magistracy was imposed - in practice, without any control and responsibility on the part of magistrates -, the author states that the action for cancellation, although it was an institution dating from communism (the extraordinary action), despise the drawback of undermining the certainty of the res judicata, stood in fact as the last resource of control before the excesses of magistrates available to citizens through the following democratic mechanism: elections, governing party, the Ministry of Justice, the general prosecutor, meaning the person enabled to introduce an action for cancellation. When according to the Emergency Ordinance 58 of 2003, the Năstase government, undergoing pressure on the part of the European Union, eliminated the action for cancellation, the last tool for controlling the magistracy was removed. The author states that this conclusion which she formulated is based on multiple interviews with magistrates and even with superior officials of the European Commission who motivated their attitude through the lack of experience in judicial matters due to the large diversity of judicial systems in the states of the European Union (a field otherwise related to national competency). In the context of this analysis of the action for cancellation, the author covers the discourse of Satu Mare of the Romanian president Ion Iliescu in 1994 whereby to the general prosecutor is requested to introduce the action for cancellation against the rulings for the restoration of the ownership in the cases in which the confiscation title lacked. Considering the reaction of the general prosecutor, the author argues that this intervention was completely justifiable from the perspective of the separation of the powers in the state, of the democratic control exercised equally on each of the three powers, and from the perspective of the fact that justice is a social service that has to eliminate injustices hence resolving social matters, and by no means to eliminate injustices by creating new ones, as well as even more serious social issues $^{34}$. I consider the argumentation brought forth by Cristina Pârâu to be solid; according to it, the judicial power has to be equal to the other two and therefore the courts do not have to substitute themselves to the legislative.

33 Cristina Pârău, The Drive for Judicial Supremacy in Judicial Independence in Transition, Anja Seibert-Fohr (ed.), op.cit., p.647.

34 Cristina Pârău, The Drive for Judicial Supremacy in Judicial Independence in Transition, Anja Seibert-Fohr ed., op. cit., pp: 656-662.
Finally, in an essay-like review of the study of David Kosař, Perils of Judicial Self-Government in Transitional Societies, starting from the comparison made by Kosař - which Iancu considers to be carried out according to all the rules of the comparative method - between the state of the justice system in the Czech Republic and in Slovakia, Bogdan Iancu criticizes the insistence of the European Union on the corporatist model of the independence of justice ensured by the Superior Council of Magistracy almost without any control and responsibility of the magistrates. Referring to the situation of Romania - otherwise, also analysed by David Kosař - Bogdan Iancu notices that this empowerment of justice, erroneous from the perspective of classic constitutionalism, has not only potential risks, but also even practical, concrete and visible consequences: "The more unsettling consequence is that the Romanian council, a corporative institution already fully insulated from majoritarian checks, has now become immune to constitutional amendments and even to peer, internal professional censure"35.

\section{The Lesson of the Research}

Noica $^{36}$ once stated that any philosophy ends with the affirmation of a banality. It is possible that the brief remembrance here of underwent research path and, especially, of the significance of this path, may seem a collection of banalities. The trajectory of man and of society makes that not rarely a respiro be appropriate, along with the remembrance of the great attachments ensuring our individual comfort, rights, and the solidarity of the community, the only one giving substance to its sovereignty.

Therefore, let us recourse to anakephalaiosis ${ }^{37}$ : the main value that we have to consider is individual sovereignty, the natural human rights; the sovereignty cannot be exercised otherwise than together by the citizens in a democratic regime under the rule of law; in the absence of sovereign community of citizens, there are no human rights, in fact, there are no guarantees for them; justice is a virtue of the community whereby solidarity is instated; the solidarity in the absence of sovereignty is just a word, and human rights as well; the accepted definition of justice is stipulated in the constitution; the constitution also comprises the

\footnotetext{
35 Bogdan Iancu, Perils of Sloganised Constitutional Concepts Notably that of ,Judicial Independence' in European Constitutional Law Review, 2017, 13, pp: 582-599, p.595.

36 Constantin Noica (1909-1987) was an important Romanian philosopher.

37 The term is used not only in the New Testament with the meaning of to recapitulate, to sum, to unite, to lead and even to resume, but also by Quintilian in Institutio Orationis, 6.1.1 with the meaning of reminding the judge and establishing the entire case before him; cf. Martin Kithen, Anakephalaiosis, in https://www.durhamcathedral.co.uk/worship-music/ regular-services/sermon-archive/anakephalaiosis
} 
provisions whereby the operation of the powers in the state is ensured; in the conditions of representative democracy, the separation and mutual control among the powers are essential for ensuring on the one hand their independence and on the other hand their responsibility; when most of the ones exercising the three powers in the state are elected (as it is the case of the President, the members of Congress and a large part of the judicial power in the United States), each of the powers is also responsible before the citizens, but also through the mechanism of checks and balances between the powers; in the situation in which the executive is appointed by the legislative, it is responsible before it and hence before the sovereign citizens; when the judicial power is appointed by the legislative, after the model of the executive power, it is responsible before it; when it is appointed by the executive, it is responsible before it; the last two situations pose important risks to the independence of judicial power; even the fact that the matter of this independence is posed shows that the judicial power is particularly important because it can be politically exploited to become a powerful weapon even against the community and individual rights, in the same manner in which it can be an equally powerful defender of the sovereignty of the community and of individual rights; the stake being so important, in Europe there was a recourse to the self-governance of the judicial power through the Superior Councils of Magistracy; this type of organisation was thought of in order to ensure independence, but there is also the risk of the corporatist type of self-protection and of the arbitrary, as well as that of occult influences, facilitated precisely by the lack of transparency specific to corporatist organisation; such an evolution means the lack of responsibility and the loss of trust in the judicial power, and finally, the very undermining of the sovereignty of citizens and of the solidarity in the community; the perils of self-governance can be substantially diminished, if not even eliminated through switching from the inquisitorial type of organisation of the process, to the adversarial type.

This gathering of all the aspects of our study clearly shows on the one hand how the judicial power which is in the service of the sovereignty of the community and individual rights can be functional, and on the other hand it offers quite a detailed scale of reference for the current debates on the matter of judicial power in Romania; this endeavour is an appeal to our fellows to embrace neutral scientific standards as strongly as possible.

\section{References}

1. Alder J (2002) General Principles of Constitutional and Administrative Law, New York, Palgrave MacMillan.

2. Aristotle (1998) Politics. Indianapolis, Hackett Publishing Company.
3. Ashworth AJ (2011) United Kingdom. In: Kevin JH, Dubber MD (Eds.), The Handbook of Comparative Criminal Law, Stanford, Stanford Law Books.

4. Augustinus A. De Trinitate.

5. Barnett H (2013) Constitutional and Administrative Law. New York, Routledge.

6. Baron de Montesquieu (2014) De l'esprit des lois in Montesquieu, Tutte le opere [1721-1754], Milano, Bompiani.

7. Benvenuti S, Paris D (2018) Judicial Self-Government in Italy: Merits, Limits and the Reality of an Export Model in German Law Journal 19(7): 1641-1669.

8. Bingham T (2011) The Rule of Law, London. Penguin Books.

9. Bradley AW, Ewing ED (2007) Constitutional And Administrative Law. Harlow, Pearson.

10. Cartledge P (2016) Democracy. A Life, Oxford, Oxford University Press.

11. Coman R, Dallara C (2012) Judicial Independence in Romani.a In: Anja Seibert-Fohr (Ed.), Judicial Independence in Transition, Heidelberg, Springer.

12. Elliott C (2011) French Criminal Law. New York, Routledge.

13. Hall DE (2009) Criminal Law and Procedure. New York, Delmar.

14. Hayek F (1978) The Constitution of Liberty. The University of Chicago Press, Chicago.

15. Iancu B (2017) Perils of Sloganised Constitutional Concepts Notably that of ,Judicial Independence'. In: European Constitutional Law Review, 13:. 582-599.

16. Kant I (1906) Grundlegung zur Metaphysik der Sitten. Leipzig, Dürr'schen Buchhandlung.

17. Kithen M, Anakephalaiosis.

18. Loveless J (2012) Criminal Law. Oxford, Oxford University Press.

19. Marx K, Kritik des Gothaer Programms.

20. Nietzsche F (1999) Jenseits von Gut und Böse. Berlin, de Gruyter.

21. Parpworth N (2012) Constitutional and Administrative Law. Oxford, Oxford University Press. 
22. Plato (1997) Gorgias. In: Plato, Complete Work. Indianapolis/Cambridge, Hackett Publishing Company.

23. Plato (1997) Republics. In: Plato, Complete Works, Indianapolis/Cambridge, Hackett Publishing Company.

24. Rawls J (1999) A Theory of Justice, Cambridge [Ma], The Belknap Press of Harvard University Press.

25. Ridley FF (1988) There is no British Constitution. Parliamentary Affairs 41: 3, pp.340-361, 342-343.
26. Rousseau JJ (2014) Emile ou De l'education. Amsterdam, Jean Neaulme Libraire, 1763.

27. Selejan-Guțan B (2018) Romania: Perils of a "Perfect Euro-Model" of Judicial Council in German Law Journal 191(7): 1707-1740.

28. Varghese S (2019) Finland's grand universal basic income experiment raises more questions than it answers.

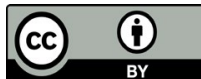

